\title{
Profiling the short, linear, non-disulfide bond-containing peptidome from the venom of the scorpion Tityus obscurus
}

\author{
Nathalia Baptista Dias ${ }^{\mathrm{a}, *}$, Bibiana Monson de Souza ${ }^{\mathrm{a}}$, Fernando Kamimura Cocchi ${ }^{\mathrm{a}}$, \\ Hipócrates M. Chalkidis ${ }^{\mathrm{b}}$, Valquíria Abrão Coronado Dorce ${ }^{\mathrm{c}}$, Mario Sergio Palma ${ }^{\mathrm{a}}$ \\ a Dept. Biology/CEIS, Institute of Biosciences of Rio Claro, University of São Paulo State (UNESP), Rio Claro, SP, Brazil \\ b Laboratory of Biological Research, Amazon College/Amazon University UNAMA, Santarem, PA, Brazil \\ ${ }^{c}$ Laboratory of Pharmacology, Butantan Institute, São Paulo, Brazil
}

\section{A R T I C L E I N F O}

\section{Keywords:}

Peptidomics

LCMS

ESI-IT-TOF/MS

Tityus obscurus

Venomics

Peptide toxin

Scorpion

\begin{abstract}
A B S T R A C T
Many scorpion accidents occur in the Brazilian Amazonian region and are frequently caused by Tityus obscurus. Approximately 5\% of the crude venom of this species is composed of short linear, non-disulfide-bridged peptides, which have not been intensively investigated. As a consequence, only a few of these peptides have been structurally and functionally characterized to date. In the present paper, the peptide fraction of the venom was subjected to peptide profiling using an LCMS-IT-TOF/MS and MS ${ }^{\mathrm{n}}$ system. The analysis detected 320 non-disulfide bond-containing peptides (NDBPs), of which twenty-seven had their sequences assigned; among them, thirteen peptides were characterized, constituting novel toxins in T. obscurus venom. Some of the novel peptides showed similarities to hypotensin-like toxins, while other peptides appear to be natural fragments of neurotoxins. The novel peptides were submitted to a series of bioassays, revealing that many are multifunctional toxins that cause, for example, pain, edema formation and hemolysis to potentiate strong inflammatory processes and alterations in the locomotion and lifting activities in the victims of stinging. Knowledge of the complex matrix of peptides composing the venom of T. obscurus will contribute to better understanding of the complex mechanism of envenoming caused by stinging accidents.

Significance: The scorpion Tityus obscurus causes many envenoming accidents of medical importance in Brazilian Amazon region; despite to this, very few is known about the toxinology of this animal. The knowledge about the venom composition and mechanisms of action is very important to understand the physiopathology processes related to the envenoming caused by this animal. The proteopeptidomic investigations of scorpion venoms in general have focused mainly the neurotoxins (which are disulfide bonds containing peptides) and large proteins. The short, linear, non-disulfide bonds containing peptides (NDBPs) represent up to 5\% of scorpion venom compositions; however, they have been few investigated in comparison with the neurotoxins. The present study used a mass spectrometric approach to detect 320 NDBPs and to sequence 27 of them; pharmacological assays permitted to characterize 13 NDBPs as novel toxins involved with inflammation, pain and edema formation.
\end{abstract}

\section{Introduction}

Species belonging to the Tityus genus, including the species $T$. $o b$ scurus (GERVAIS, 1843) (previously known as Tityus paraensis (KRAEPELIN, 1896) and Tityus cambridgei (POCOCK, 1897), are responsible for the majority of scorpion accidents in Brazil [1]). T. obscurus is responsible for many envenomation accidents, especially in the Amazon region [2].

The number of accidents caused by scorpion stings is increasing due to intensification of human activities in forest regions [3]. Scorpionism is a medical-sanitary problem of great importance, and patients with severe signs of scorpion envenoming primarily present cardiovascular events, including acute heart failure and respiratory distress syndrome. In addition, the victims of $T$. obscurus stings have systemic manifestations, including neurological disorders in $97.2 \%$ cases and electric shock-like sensations throughout the body (in $88.9 \%$ patients) [4]. In addition, some publications have reported severe health problems following scorpion stinging; Torrez et al. [5] reported 58 accidents presumably caused by $T$. obscurus in the Brazilian Amazon, with symptoms such as cerebellar ataxia, dysdiadochokinesia, dysmetry, dysarthria, nausea and vomiting in most patients; cardiomyopathy is also frequently reported $[4,6]$. Apparently, the venom from T. obscurus is less

\footnotetext{
* Corresponding author.

E-mail address: nathdias@rc.unesp.br (N.B. Dias).
} 
toxic than that of $T$. serratus but is still able to cause lethality in mice, as well other typical effects of Tityus venoms with reduced intensities [7]. The biochemical characterization of some toxins of this venom are focused on classical approaches of neurotoxins acting on sodium and/or potassium channels [8-13].

Scorpion venom contains an enormous number of peptide toxins, requiring numerous publications to extensively cover this subject; however, most articles involving scorpion venom investigations primarily describe clinical symptoms and epidemiology of scorpionism and do not provide a detailed characterization of venom composition, structure assignment and the mode of action of the toxins. Peptides represent the most abundant components of scorpion venom [14,15] and can be generically classified into two structural classes: disulfidebridged peptides (DBPs) and non-disulfide-bridged peptides (NDBPs) [15]. The DBPs are the most abundant components of scorpion venoms and are classically extracted in aqueous solvents and initially fractionated using gel-filtration chromatography; each fraction may be rechromatographed under RP-HPLC, resulting in pure peptides [16-18]. This experimental approach permits the extraction and purification of many peptides containing 30 to 80 amino acid residues, which constitute the most known scorpion venom toxins to date [19]. The NDBPs are mostly unknown and have been rarely investigated; only a few have been thoroughly characterized [15,20-23]. These peptides are directly extracted with acetonitrile (ACN) from the crude scorpion venoms and purified using RP-HPLC. While most DBPs are neurotoxins, it was reported that most NDBPs are composed of short, linear, polycationic amphipathic peptides, which may present a wide range of biological activities such as antimicrobial action, hemolytic disorders, activation of cell signaling processes, inflammation, immune-modulation and blood pressure changes [15,20-24]. The identification of these toxins is essential for characterizing the pharmacological symptoms observed during the envenoming process [25].

A detailed characterization of animal venom based on the profiling of proteomics and peptidomics has been performed using mass spectrometric analysis. The use of LC-MS and MS/MS has been crucial for detection, sequencing, and identification of the rich composition of peptides/proteins from animal venom, contributing to the assignment of the global proteopeptidomic profiles of various Arthropod venoms such as social wasps [11,26-29], ants [30], honeybees [31], and spiders $[32,33]$. The assignment of the proteome complement from scorpion venom has also benefited from the use of mass spectrometric analysis; a detailed analysis of Tityus spp. venom identified hundreds of components, constituting a complex composition of peptides with molecular masses from 2500 to 8000 Da (mostly DBPs), presenting activity in the modulation of $\mathrm{Na}^{+}, \mathrm{K}^{+}, \mathrm{Ca}^{++}$and $\mathrm{Cl}^{-}$currents; proline-rich peptides, bradykinin-potentiating peptides (BPP) (NDBPs), proteins such as hyaluronidase, various lysozymes, proteinases (carboxypeptidases, endopeptidases, aminopeptidases), and metalloproteinases were also identified [21,25,34-40]. It was reported that the composition of Tityus serrulatus venom is composed of neurotoxins, enzymes, diuretic peptides, bradykinin-potentiating peptides (BPPs) and antimicrobial peptides, among other components [41-44]. However, the peptidome approach has only been applied in a few animal studies [15,20-23].

MALDI-TOF-TOF and de novo sequencing were used to assign the sequence of 28 peptides from $400 \mathrm{Da}$ to $3900 \mathrm{Da}$ in venom from the $T$. serrulatus, mostly as fragments of Pape proteins, corresponding to sequences from the $\mathrm{N}$-terminal region of the TsK $\beta$ (scorpine-like) toxin, from potassium channel toxins (other than the k-beta ones), and from hypotensins $[45,46]$.

Nascimento et al. [43] investigated the general profile of polypeptide components from the venom of various scorpion species from $900 \mathrm{Da}$ to $17.000 \mathrm{Da}$; the authors reported 632 components in T. stigmurus, 383 components in T. serrulatus, 464 components in T. bahiensis, 554 in Leiurus hebraeus, and 380 components in L.q. quinquestriatus; however, no short, linear peptide sequence was assigned in these studies.
Considering the medical importance of scorpionism accidents in northern Brazil, especially those caused by T. obscurus, as well the inadequate knowledge of venom composition for this scorpion species, we focused the present study on the sequence assignments and functional characterization of NDBPs from the venom of T. obscurus. For this purpose, the venom was extracted with acetonitrile (ACN) and subjected to LC-ESI-IT/MS and MS ${ }^{\mathrm{n}}$ analysis to perform peptidome profiling. The sequences of 27 NDBPs were assigned, and thirteen NDBPs were synthesized on in solid phase, purified and assayed for mast cell degranulation, hemolysis, delivery of lactate dehydrogenase activity (LDH) from mast cells, antibiosis, edema formation, and evaluation of locomotion/rearing.

\section{Material and methods}

\subsection{Biological material}

Tityus obscurus scorpions were collected in the neighborhood of Santarem, AM, northern Brazil, by the staff of the Butantan Institute (São Paulo, SP, Brazil) with SISBIO/IBAMA authorization (protocols nos. 21483-2 and 20158-1); the animals were maintained in plastic boxes with water ad libitum and regularly fed cockroaches. Access to the genetic patrimony of this scorpion species was formally authorized by CGEN (protocol no. 010803/2013-0). The venom was obtained via electric stimulation of telsons, collected with micropipettes, lyophilized, frozen and stored at $-20{ }^{\circ} \mathrm{C}$. The crude venom was donated to the present study. The venom was solubilized in $50 \%(\mathrm{v} / \mathrm{v})$ ACN containing a mixture of Protease Inhibitor Cocktail ( $2 \mathrm{mM}$ AEBSF, $0.3 \mu \mathrm{M}$ aprotinin, $130 \mu \mathrm{M}$ bestatin hydrochloride, $1 \mathrm{mM}, 2 \mathrm{mM}$ EDTA, $0.1 \mathrm{mM}$

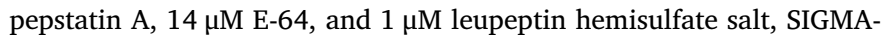
ALDRICH. St. Louis, USA). The extract was centrifuged at $10,000 \times g$ for $20 \mathrm{~min}$ at $4{ }^{\circ} \mathrm{C}$, and the pellets were discarded and the supernatant was lyophilized and maintained at $-20{ }^{\circ} \mathrm{C}$ until use. Three different lots of crude venom were used to prepare three different replicate samples.

\subsubsection{Animals}

Male Swiss mice weighing between 25 and $30 \mathrm{~g}$ were used throughout this study. Mice were housed under controlled humidity at $22{ }^{\circ} \mathrm{C} \pm 1$ and subjected to a 12-h light/dark cycle in a sound-attenuated room. Food and water were available ad libitum, and mice were taken to the testing room at least one day before the experiment. All behavioral testing was performed between 9:00 am and 4:00 pm. Each mouse was used only once. All experiments were performed in accordance with the guidelines for the ethical use of conscious animals in pain research published by the National Academy of Sciences (http:// www.nap.edu/catalog/5140.html). The procedures were approved by the Institutional Animal Care Committee at São Paulo State University, UNESP campus Rio Claro, SP (CEUA-IB-UNESP-CRC, Protocol no. 1984). Efforts were made to minimize the number of animals used and their suffering.

\section{2. $L C-M S$ and $L C M S^{n}$ analysis}

Approximately $50 \mu \mathrm{g}$ of the peptide-rich fraction from T. obscurus venom was solubilized in $100 \mu \mathrm{L}$ of $50 \%(\mathrm{v} / \mathrm{v}) \mathrm{ACN}$ and fractionated in an LC-MS system using an X-Bridge BEH 130 C-18 column $(100 \mathrm{~mm} \times 2.1 \mathrm{~mm} ; 3.5 \mu \mathrm{m})$ (Waters, Massachusetts, USA) at a flow rate of $200 \mu \mathrm{L} / \mathrm{min}$. Elution was performed under gradient conditions from 5 to $95 \%(\mathrm{v} / \mathrm{v})$ ACN (containing $0.1 \%(\mathrm{v} / \mathrm{v})$ TFA) between 0 and $95 \mathrm{~min}$ at $30^{\circ} \mathrm{C}$. The eluent was monitored at $215 \mathrm{~nm}$ with a UV-DAD detector, mod. SPD-M10A (SHIMADZU, Kyoto, Japan) coupled to an ITTOF/MS and $\mathrm{MS}^{\mathrm{n}}$ mass spectrometer system equipped with an electrospray ionization source (Shimadzu, Kyoto, Japan).

Spectra were acquired in positive mode, with activation of datadependent acquisition (DDA), which permits a switch automatically 
from MS to $\mathrm{MS}^{2}$ mode. The electrospray voltage was set to $4.5 \mathrm{kV}$, the CDL temperature was set to $200{ }^{\circ} \mathrm{C}$, the block heater temperature was adjusted to $200{ }^{\circ} \mathrm{C}$, the nebulizer gas (N2) flow was $1.5 \mathrm{~L} / \mathrm{min}$, the trap cooling gas (Ar) flow was $95 \mathrm{~mL} / \mathrm{min}$, the ion trap pressure was $1.7 \times 10^{-2} \mathrm{~Pa}$, the TOF region pressure was $1.5 \times 10^{4} \mathrm{~Pa}$, and the ion accumulation time was $50 \mathrm{~ms}$. The top five ions from each MS spectrum were selected as precursors (Top N) for fragmentation in $\mathrm{MS}^{2}$, as typically used in DDA experiments. The collision energy was set at $35 \%$ both for $\mathrm{MS}^{2}$ and $\mathrm{MS}^{3}$, and the collision gas set to $20 \%$. Autotuning was performed in the presence of Na-TFA solution (TFA $0.1 \%(\mathrm{v} / \mathrm{v}) 10 \mathrm{mM}$ $\mathrm{NaOH}$ at $\mathrm{pH} 3.5$ ). The mass spectral resolution was approximately 10,000 FWHM, and error was approximately $3.08 \mathrm{ppm}$.

\subsection{Acetylation of lysine residues}

The acetylation of Lys residues was used to distinguish between the quasi-isobaric amino acid residues of Lys and Gln (Lys $=128.09496$ / Gln $=128.05858$ ) during peptide sequencing by mass spectrometry. The acetylation reagent was prepared by mixing $20 \mu \mathrm{L}$ of acetic anhydride with $60 \mu \mathrm{L}$ of methanol, and the peptide of interest $(1 \mathrm{nmol} \mathrm{so}-$ lubilized in $20 \mu \mathrm{L}$ of $50 \mathrm{mM}$ ammonium bicarbonate $\mathrm{pH}$ 7.0). Then, $50 \mu \mathrm{L}$ of the acetylation reagent was mixed with $20 \mu \mathrm{L}$ of the peptide solution and incubated at $25^{\circ} \mathrm{C}$ for $60 \mathrm{~min}$. The mixture was lyophilized to dryness and reconstituted in $50 \%(\mathrm{v} / \mathrm{v})$ ACN for mass spectrometry analysis.

\subsection{Peptide synthesis}

The peptides were synthesized by step-wise solid-phase synthesis using N-9-fluorophenylmethoxy-carbonyl (Fmoc) chemistry with Novasyn TGS resin (NOVABIOCHEM, Germany) using an automated peptide synthesizer (PROTEIN TECHNOLOGY INC., mod. Prelude; USA). Side-chain protective groups included $t$-butyl for serine and $t$ butoxycarbonyl for lysine. Cleavage of the peptide resin complexes was performed with trifluoroacetic acid, 1,2-ethanedithiol, anisole, phenol, and water (82.5:2.5:5:5:5 by volume, respectively) for $2 \mathrm{~h}$. The peptides were precipitated with cooled ethyl ether $\left(4^{\circ} \mathrm{C}\right)$. The crude peptides were solubilized in water and purified in a RP-HPLC system mod. LC-8A (SHIMADZU, Kyoto, Japan), using a semi-preparative column (SHISEIDO C-18, $250 \mathrm{~mm} \times 10 \mathrm{~mm}, 5 \mathrm{~mm}$ ) under isocratic conditions with $55 \%(\mathrm{v} / \mathrm{v})$ ACN (containing $0.1 \%(\mathrm{v} / \mathrm{v}) \mathrm{TFA}$ ) at a flow rate of $2 \mathrm{~mL} / \mathrm{min}$. The elution was monitored at $215 \mathrm{~nm}$ with a UV-DAD detector, mod. SPD-M10A (SHIMADZU, Kyoto, Japan), and each eluted fraction was manually collected; the purity was checked using mass spectrometry analysis. The synthetic peptides were used to perform all bioassays described below.

\subsection{Biological assays}

\subsubsection{Hemolytic activity}

Washed rat red blood cells (WRRBC) were used to evaluate the hemolytic activity of the peptides. WRRBC were prepared by washing Wistar RRBC three times with $50 \mathrm{~mL}$ of saline solution $(0.85 \%(\mathrm{w} / \mathrm{v})$ $\mathrm{NaCl}$, containing $10 \mathrm{mM} \mathrm{CaCl}_{2}$ ), and re-suspended in $50 \mathrm{~mL}$ of the same solution. Aliquots of WRRBC $(0.5 \% \mathrm{v} / \mathrm{v})$ were incubated at $37^{\circ} \mathrm{C}$ in the presence of each synthetic peptide for $120 \mathrm{~min}$ with gentle mixing. Samples were centrifuged, and the absorbance of the supernatants was measured at $540 \mathrm{~nm}$. The absorbance measured from lysed WRRBC in the presence of $1 \%(\mathrm{v} / \mathrm{v})$ Triton X-100 was considered $100 \%$.

\subsubsection{Measurement of lactate dehydrogenase $(L D H)$ release from mast cells}

The release of LDH from mast cell cytoplasm to the surrounding environment is an indicator of mast cell lysis. LDH catalyzes the reversible reduction of pyruvate to lactate with NADH as a coenzyme. The LDH activity was assayed with the supernatant suspension resulting from the peritoneal mast cell degranulation assays as described above.
The assay kit UV-LDH (BIOTECNICA, Brazil) was used as follows: $20 \mu \mathrm{L}$ of peritoneal mast cell supernatant suspension was incubated with $800 \mu \mathrm{L}$ of $50 \mathrm{mM}$ Tris buffer, $\mathrm{pH} 7.4$, containing $1.2 \mathrm{mM}$ pyruvic acid and $5 \mathrm{mM}$ EDTA (SIGMA-ALDRICH, Saint Louis, USA) for $5 \mathrm{~min}$ at $25{ }^{\circ} \mathrm{C}$. The results were initially calculated as catalytic units (mmoles NADH consumed per min at $\mathrm{pH}$ 7.4) and converted into relative activity by measuring the total amount of LDH activity of rat mast cells lysed in the presence of $0.1 \%(\mathrm{v} / \mathrm{v})$ Triton $\mathrm{X}-100$ (this value was considered a reference for $100 \%$ ). The results were expressed as an average ( \pm SD) of five experiments.

\subsubsection{Mast cell degranulation activity}

Mast cell degranulation was determined by measuring the release of $\beta$-D-glucosaminidase in the presence of synthetic peptides. Mast cells were obtained by peritoneal washing of adult Wistar rats with a solution containing $0.877 \mathrm{~g} \mathrm{NaCl}, 0.028 \mathrm{~g} \mathrm{KCl}, 0.043 \mathrm{~g} \mathrm{NaH} 2 \mathrm{PO} 4,0.048 \mathrm{~g}$ KH2PO4, $0.10 \mathrm{~g}$ glucose, $0.10 \mathrm{~g}$ BSA, $90 \mathrm{~mL}$ of a $2 \mathrm{M} \mathrm{CaCl} 2$ solution and $50 \mu \mathrm{L}$ Liquemine (heparin, ROCHE) in $100 \mathrm{~mL}$ water. Mast cells were incubated in the presence of peptides for $15 \mathrm{~min}$ at $37^{\circ} \mathrm{C}$. After centrifugation, $50 \mu \mathrm{L}$ of mast cell suspension was added to $50 \mu \mathrm{L}$ of the substrate $\quad[3.4 \mathrm{mg}$ of $p$-nitrophenyl- $N$-acetyl- $\beta$-D-glucosaminidine (SIGMA-ALDRICH, Saint Louis, USA) dissolved in $10 \mathrm{~mL}$ of $200 \mathrm{mM}$ sodium citrate, $\mathrm{pH} 4.5$ ] and incubated for $6 \mathrm{~h}$ at $37^{\circ} \mathrm{C}$. The reaction was stopped by the addition of $150 \mu \mathrm{L}$ of $0.2 \mathrm{M}$ Tris and the absorbance was measured at $405 \mathrm{~nm}$ in a spectrophotometer (mod. Biotrack, AMERSHAM BIOSCIENCES, Sweden). The values are expressed as the percentage of total $\beta$-D-glucosaminidase lysed from mast cells in the presence of $0.1 \%(\mathrm{v} / \mathrm{v})$ Triton X-100.

\subsubsection{Antimicrobial activity}

The minimal inhibitory concentrations (MIC) of the peptides were determined based on methods described by Meletiadis et al. [47]. The following microorganisms were used: E. coli (CCT 1457), S. aureus (CCT 6538), S. pneumoniae (ATCC11733), and E. aerogenes (CCT2572). The experiment was performed in 96-well plates. Bacterial cells were suspended in sterile culture medium; the inoculum size was $1 \times 10^{4}$ cells $\mathrm{m} / \mathrm{L}$ in Müller-Hinton broth (DIFCO), as confirmed by the use of McFarland scale. From this culture, $50 \mu \mathrm{L}$ was spread onto the micro-plate previously containing $50 \mu \mathrm{L}$ of Müller-Hinton broth, resulting in a final cell density of $1.5 \times 10^{3} \mathrm{cell} / \mathrm{mL}$. Cells were incubated at $37^{\circ} \mathrm{C}$ for $18 \mathrm{~h}$ in the presence of $100 \mu \mathrm{L}$ of each peptide solution in concentrations ranging from 0.8 to $500 \mu \mathrm{g} / \mathrm{mL}$. After incubation, $10 \mu \mathrm{L}$ of a triphenyltetrazolium chloride (TTC) (MALLINCKRODT) solution (final concentration $0.05 \%, \mathrm{w} / \mathrm{v}$ ) was added to each well. The plate was incubated at $37{ }^{\circ} \mathrm{C}$ for $2 \mathrm{~h}$. Live colonies reduce TTC to a dark-red color, while those with reduced respiratory function cannot and remain unchanged. Thus, the results were expressed as the MIC that inhibits all colony forming units. Chloramphenicol (Sigma-Aldrich) was used as a standard antibiotic, and the negative controls were the wells containing only culture medium. The results were expressed as the mean of three experiments.

\subsubsection{Hyperalgesic and edematogenic effects}

Male Swiss mice weighing between 25 and $30 \mathrm{~g}$ were used throughout this study. The housing of mice occurred under controlled humidity $(65 \% \pm 5 \%)$ and temperature $\left(22{ }^{\circ} \mathrm{C} \pm 1\right)$, in a sound-attenuated room subjected to a $12 \mathrm{~h}$ light-dark cycle. Food and water were available ad libitum, and mice were taken to the testing room at least $1 \mathrm{~h}$ before the experiment. All behavioral testing was performed between 9:00 a.m. and 4:00 p.m. The mice were used only once. All experiments were completed in accordance with the Guidelines for the Ethical Use of Conscious Animals in Pain Research published by the International Association for the Study of Pain [48] and the EC Directive 86/609/EEC for Animal Experiments. The animal manipulation protocols were approved by the Institutional Animals Care Committee (CEUA-IB, protocol 016/2011). 


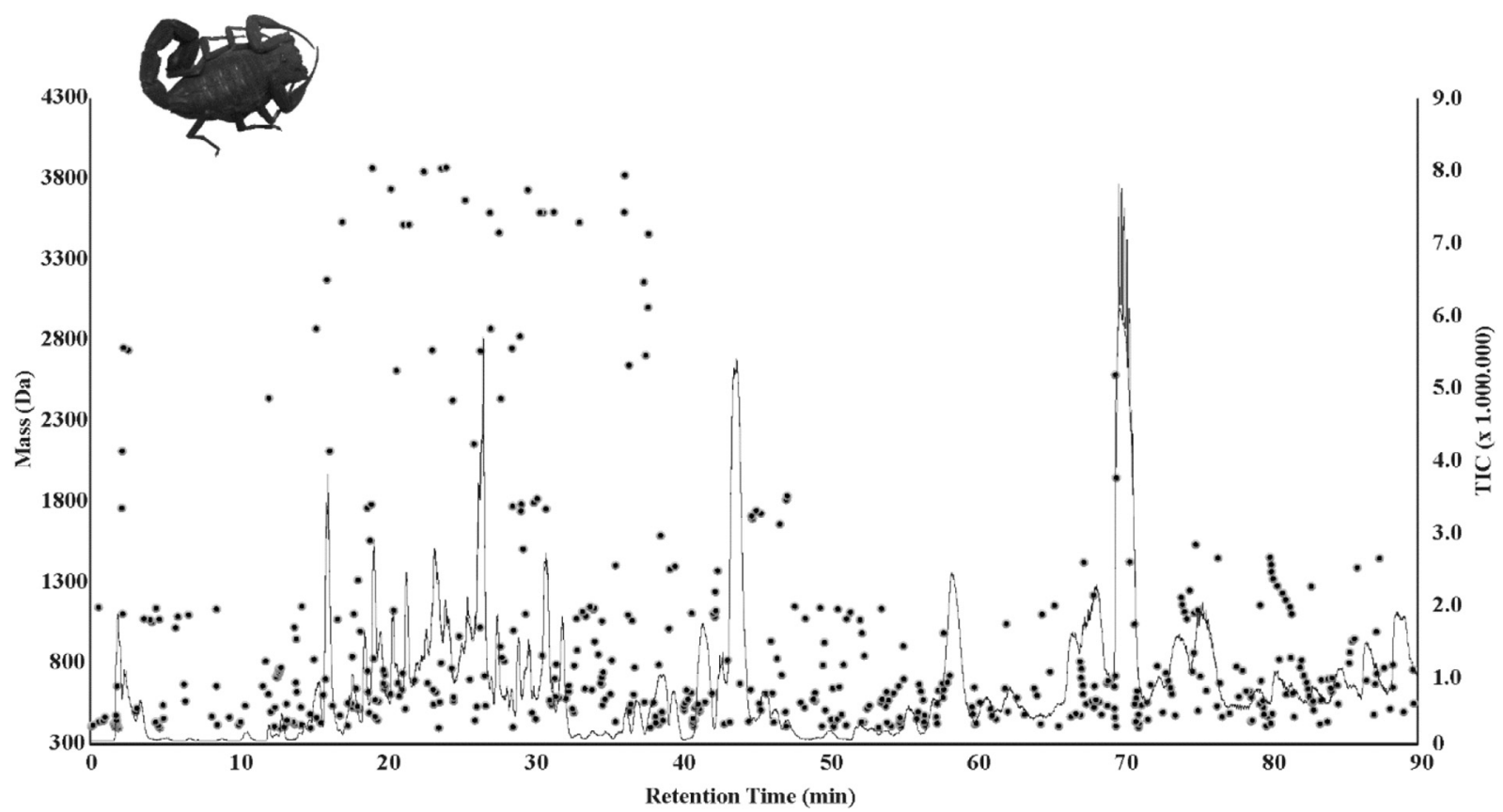

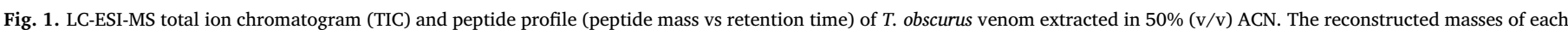

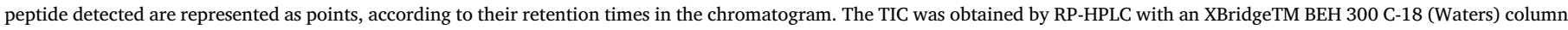

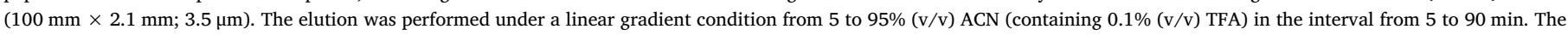
elution was performed at $30^{\circ} \mathrm{C}$ at a flow rate of $200 \mu \mathrm{L} / \mathrm{min}$.

Mice were placed in appropriate acrylic cages with a wire-gridded floor $30 \mathrm{~min}$ before the assay. During this adaptation period, the paws of mice were poked 2-3 times. Before paw stimulation, the animals remained quiet, presenting neither exploratory movements nor resting on their paws. In these experiments, an electronic von Frey anesthesiometer, a paw pressure meter fitted with a $0.5 \mathrm{~mm}^{2}$ plastic tip (IITC Inc., LIFE SCIENCE INSTRUMENTS, Woodland Hills, CA, USA) was used. A mirror fitted below the gridding floor provided a view of hind paw movements. The use of an electronic von Frey instrument (INSIGHT, Ribeirão Preto, SP, Brazil) permitted the automatic register of the force intensity of the stimulus by the time of paw withdraw. The maximal force applied was $18 \mathrm{~g}$. The stimulations were repeated until the mice presented at least two similar measurements. The hyperalgesic effect was induced by injection through the intraplantar (i.pl.) route into one of the hind paws, with either carrageenan $(300 \mu \mathrm{g})$ or each peptide $(25 \mu \mathrm{g})$. The results are reported as the D (delta) withdrawal threshold $(\mathrm{g})$.

For evaluation of nociceptive activity, peptides were dissolved in sterile saline $(25 \mu \mathrm{g} / 50 \mu \mathrm{L}$ saline $)$ and applied by i.pl. route in one of the hind paws of the mice. The tip of the pressure meter was introduced in the central area of the hind paw (where the compounds were applied with the help of a $26 \mathrm{~g}$ needle) to measure the intensity and the time of paw withdraw. Nociceptivity was evaluated at 60, 180 and $300 \mathrm{~min}$ after peptide application and compared to the control. Carrageenan (MARINE COLLOIDS, $300 \mu \mathrm{g} / 50 \mu \mathrm{L}$ sterile saline) was used as the positive control, while the negative control was performed with sterile saline.

Edema was induced by the injection of carrageenan (or peptides) into one of the hind paws by the intraplantar (i.pl.) route. The increase in the volume of paws (edema) at the region of tibio-tarsal articulation was measured with a digital paquimeter (MITUTOYO, São Paulo, SP, Brazil). The difference between the values measured in each paw was expressed as the percent increase in paw volume.

2.5.6. Assessment of and evaluation of locomotion/rearing activity (open field test)

An acrylic arena divided into 25 squares was used to evaluate the general movement activity of the animals. Animals were placed in the observation arena for 2 min for acclimatization and then positioned in the center of the field. Two parameters were used: the number of squares crossed and the rearings (number of times the mouse stood on its hind limbs). The data were collected for $3 \mathrm{~min}$ after $15 \mathrm{~min}$ of i.p. (intra peritoneal) injection of peptide solution $(25 \mu \mathrm{g} / 50 \mu \mathrm{L})$ or saline ( $50 \mu \mathrm{L}$, in the control group).

\subsection{Statistical analysis}

A two-way analysis of variance (ANOVA) was used to compare the groups and doses over the entire range. Three factors were analyzed: treatments, time and the time vs. treatment interaction. When a significant time vs. treatment interaction was detected, a one-way ANOVA followed by Tukey's test was performed for each time point to distinguish the dose effects [49]. The results with $\mathrm{p}<0.05$ were considered significant.

\section{Results and discussion}

\subsection{Peptidome analysis}

To improve our knowledge of the biochemical composition of peptide toxins from $T$. obscurus, venom was submitted to peptide profiling. For this purpose, the soluble fraction from $1 \mathrm{mg}$ of crude venom was extracted with $50 \%(\mathrm{v} / \mathrm{v}) \mathrm{ACN}$, resulting in $50 \mu \mathrm{g}$ of the short, linear peptide-rich fraction, which in turn was fractionated under RPHPLC coupled to a LC-ESI-IT-TOF-MS and MS ${ }^{\mathrm{n}}$ system, as described above in the methods section.

LCMS analysis of the sample directly extracted in ACN revealed a rich peptide composition; considering the total number of peptides detected in the total ion chromatogram (TIC) and the accumulated peptides from 400 to $4000 \mathrm{Da}, 517 \mathrm{MS} / \mathrm{MS}$ spectra were selected and acquired over the 90-min chromatogram (Figs. 1 and 2; Table S1). The DBPs represent the most abundant components of scorpion venoms, which are generally extracted in aqueous buffers (like the proteins) and fractioned under RP-HPLC [16-18]. In the present investigation, the 


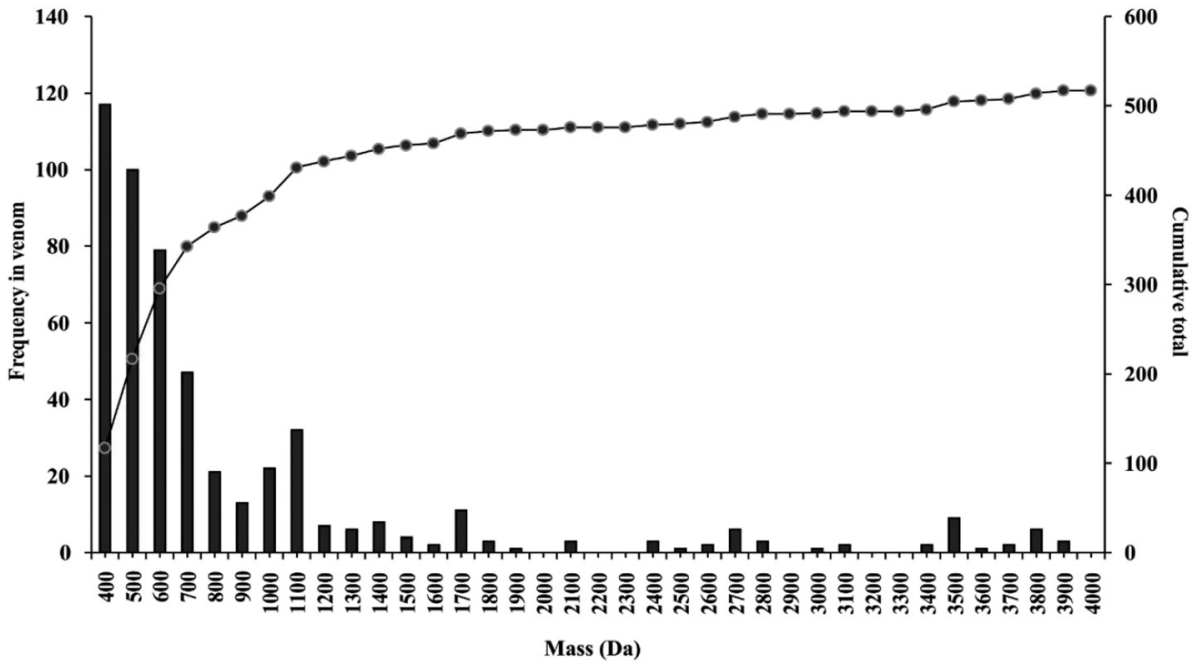

Fig. 2. Histogram of peptide abundance by mass (100 Da bins). Overlaid curves show cumulative total peptide number. extraction was first performed in $50 \%(\mathrm{v} / \mathrm{v})$ acetonitrile, so the NDBPs were mostly extracted in relation to the DBPs. A careful observation of Table S1 reveals that from the 517 precursor ions selected for the acquisition of MS/MS spectra, 157 represent analytical redundancies. Thus, a total of 360 peptides were detected in the mass range from 400 to $4000 \mathrm{Da}$, of which 40 peptides presented molecular masses from 2115 to $3926 \mathrm{Da}$ (26 with molecular masses above $3200 \mathrm{Da}$ and are possibly DBPs/neurotoxins). The other 320 peptides are primarily composed of NDBPs.

The mass spectrometric analysis was performed using ESI as an ionization source in the positive and negative acquisition mode; however, because the peptide fraction of this venom is composed of polycationic components, only data obtained in the positive mode are presented in this publication, resulting in much more intense peaks than the negative mode data. The venom sample components were distributed over the molar mass range of $400-4000 \mathrm{Da}$, which together comprise up to $5 \%$ of the dry weight of the venom. This analysis allowed the preparation of the profile of mass distribution shown in Fig. 2. It may be observed that the abundance of mass values is in the interval between $400 \mathrm{Da}$ and $700 \mathrm{Da}$. Generally, the large peptides elute on RP-HPLC columns; the hydrophilic ones elute first under mobile phases rich in water, while the hydrophobic ones elute later, under mobile phases rich in ACN. However, in the present study, the NDSBs appear to elute throughout the chromatogram. To emphasize this feature, Table 1 also shows the GRAVY Index for the NDBPs from T. obscurus venom, calculated with the tool ProtoParam (http://web.expasy.org/protoparam/ ). Algorithms used to calculate the average hydropathy depend on amino acid sequences and are based on the work of Kyte and Dolittle [50,51]; a positive index indicates a hydrophobic protein/peptide, while a negative index indicates hydrophilic character. It is expected that peptides with negative indexes should elute first, while those with positive indexes should elute later. However, a detailed observation of Table 1 reveals that the NDSB peptides elute throughout the chromatogram. To explain this chemical behavior of the NDSB peptides, it must be acknowledged that the GRAVY index tends to underestimate hydrophobicity when the elements of secondary structure bury charged residues; in addition, the index does not work well for too-short sequences (less than five residues) [52,53]. In addition, other factors may influence the retention times of short, linear peptides: i) the stability of elements of secondary structure generally results in higher retention times than predicted by the index, as the polarity of peptide backbone is minimized [50,51]; ii) it has been shown that the detection of peptides in RP-HPLC coupled to an ESI/MS system tends to demonstrate a counter-intuitive preference for some peptide conformations in relation to other proline-containing peptides [52], which generally suffer slow conformational changes under equilibrium due to the cis-trans isomerism of Pro-residues, with reasonable changes in retention times for the same peptides, which may elute with different retention times in the same chromatogram in RP-HPLC [53]. A careful observation of Table 1 reveals that 18 of the 27 peptides presented Pro residues in their sequences, which may interfere with their conformations, their interactions with the stationary phase of the RP-column and therefore their retention times.

In the present study we focused on the short, linear NDSB peptides; we considered the analysis of 320 tandem mass spectra obtained for these peptides. Most did not present analytical features to render their interpretation in reliable amino acid sequences. The reasons for the selection of the 27 peptides in the present study were i) high abundances (as indicated by spectral counting of each peptide component detected) (Table 1), which resulted in relatively high peak intensities (in tandem mass spectra); ii) reliable mass spectra under CID conditions, with a large number of sequence-related fragment ions; iii) the presence of two residues of Pro in sequences, which frequently causes difficulties in spectral interpretation due the occurrence of gaps in the spectra. Despite the high abundance of some peptides, their tandem mass spectra did not result in reliable mass spectra due to high hydrophobicity and therefore poor ionization and overall fragmentation pattern with a poor series of sequence-related fragment ions. Meanwhile, other peptides occurred in reduced abundance but ionized quite well and fragmented under CID conditions, resulting in large series of sequence-related fragment-ions. Table 1 shows some examples of peptides occurring in reduced abundance (reduced spectral counts) with intense signals and a large series of sequence-related fragment ions. We selected the 27 tandem mass spectra that permitted unambiguous sequence assignment of NDBPs.

The interpretation of $\mathrm{MS}^{2}$ spectra obtained under CID conditions across the mass chromatogram was used to assign the peptide sequence through the subtraction of the $m / z$ values between consecutive $b$-ions (or $y$-ions), permitting the assignment of peptide sequences. This procedure allowed the almost complete sequence assignment of many peptides, a few apparent ambiguities in relation to the isobaric residues $\mathrm{I} / \mathrm{L}$ and $\mathrm{K} / \mathrm{Q}$ remain. The ambiguities I/L for residues positioned inside the peptide chain were solved using ion fragments of the $d$ - and/or $w$ type, specific for the fragmentation of the side chains of I and L residues. This was initially done by simulating the "candidate sequences" (containing I or L residues) fragmentation under CID conditions using the algorithm Protein Prospector-MS Product (http://prospector.ucsf. edu/prospector/cgi-bin/msform.cgi?form $=$ msproduct); the $m / z$ values of virtual $d$ - and $w$-fragment ions were manually searched for in the experimental $\mathrm{MS}^{2}$ spectra to assign I or L residues where necessary; $\mathrm{m} / \mathrm{z}$ values with signal/noise above 5 were accepted. The $\mathrm{N}$-terminal residue ambiguity was solved by synthesizing two sequences per peptide (with I 
Table 1

Profile of peptides sequenced from venom of the scorpion Tityus obscurus.

\begin{tabular}{|c|c|c|c|c|c|}
\hline Peptide number & Amino acid sequences & Molecular mass (Da) & Retention time (min) & Spectral count & GRAVY index \\
\hline Pep-1 & AEIDFSGIPEDIIKQI-OH & 1786.94 & 34.2 & 22 & 0.181 \\
\hline Pep-2 & GCDALLSGDHGGLLSANGC-OH & 1758.77 & 51.3 & 15 & 0.342 \\
\hline Pep-3 & LIPNDQLRSI-OH & 1167.63 & 74.5 & 66 & -0.080 \\
\hline Pep-4 & NIALGQDQSGR-NH2 & 1156.74 & 18.1 & 54 & -0.909 \\
\hline Pep-5 & KIKEKLIEA-OH & 1070.67 & 52.0 & 23 & -0.456 \\
\hline Pep-6 & WPNKIEPGK-OH & 1067.57 & 37.4 & 216 & -1.644 \\
\hline Pep-7 & KETNAKPPA-OH & 954.51 & 8.1 & 34 & -1.678 \\
\hline Pep-8 & KIITPPIR-OH & 936.53 & 34.8 & 116 & 0.150 \\
\hline Pep-9 & KPVEPVG-OH & 724.47 & 20.5 & 176 & -0.371 \\
\hline Pep-10 & SESNTCG-OH & 696.26 & 26.8 & 496 & -1.029 \\
\hline Pep-11 & NAKPPA-OH & 596.31 & 78.2 & 202 & -1.167 \\
\hline Pep-12 & ILTGKLKCK-OH & 1002.60 & 28.4 & 60 & 0.200 \\
\hline Pep-13 & ILPNDK-OH & 698.39 & 20.1 & 372 & -0.700 \\
\hline Pep-14 & VYWLPAVLGSLLGFTP-OH & 1731.99 & 45.3 & 25 & 1.281 \\
\hline Pep-15 & RPPHNPGFLTVYN-OH & 1510.71 & 29.6 & 32 & -0.854 \\
\hline Pep-16 & PHWLFFGVSVLC-OH & 1403.75 & 39.1 & 76 & 1.433 \\
\hline Pep-17 & VTLTLPPAES-NH2 & 1025.67 & 14.5 & 22 & 0.470 \\
\hline Pep-18 & KETNAKPP-OH & 883.48 & 8.7 & 116 & -2.112 \\
\hline Pep-19 & LFGAFALV-OH & 837.45 & 81.0 & 960 & 2.575 \\
\hline Pep-20 & HERLLGP-OH & 820.45 & 35.4 & 199 & -0.800 \\
\hline Pep-21 & TVPDLEM-NH2 & 802.52 & 87.3 & 94 & 0.086 \\
\hline Pep-22 & HGCIGCGR-NH2 & 800.36 & 6.0 & 32 & 0.075 \\
\hline Pep-23 & PCFTLPG-OH & 733.38 & 26.5 & 900 & 0.686 \\
\hline Pep-24 & NAKPP-OH & 525.29 & 61.4 & 324 & -1.760 \\
\hline Pep-25 & K/QPVVG-OH & 498.31 & 33.2 & 298 & $0.500 / 0.590$ \\
\hline Pep-26 & SILK-OH & 459.32 & 45.8 & 638 & n.d.* \\
\hline Pep-27 & КРPA-OH & 411.24 & 3.6 & 210 & n.d. ${ }^{*}$ \\
\hline
\end{tabular}

(*) The sequence must have at least 5 residue to have the GAVY Index calculated by ProtoParam algorithm.

or $\mathrm{L}$ positioned at the $\mathrm{N}$-terminus), which in turn were submitted to LCMS-IT-TOF/MS analysis. The molecular masses and retention times of synthetic and natural peptides were compared to each other. To solve the K/Q ambiguity, the samples were derivatized with acetic anhydride and submitted to mass spectrometric analysis under CID conditions. The $\varepsilon$-amino group from the side chain of $\mathrm{K}$ residues and the $\alpha$-amino group of the N-terminal residue of each peptide become acetylated, contributing increments of 42 mass units per acetyl group incorporated into the peptide chain. The side chain of the $\mathrm{Q}$ residue does not react with acetic anhydride. To save space in the manuscript and to present the data more objectively and less repetitively, we decided to present and discuss the complete set of sequencing data in the manuscript body for a typical peptide, while data for the remaining peptides are presented in the Supplementary section.

Thus, the peptide eluting at a retention time of 32.4 min was selected as an example of the application of mass spectrometry as an analytical strategy for sequencing purposes (Fig. 3A and B), while sequencing data for the remaining peptides were presented in Supplementary figures (Figs. S1 to S26). Fig. 3A shows the MS ${ }^{1}$ spectrum of this peptide, with a very intense peak corresponding to the ion of $m / z$ 894.472 as $[\mathrm{M}+2 \mathrm{H}]^{+2}$. The deconvolution of these data indicates that the peptide presents a molecular mass of $1786.94 \mathrm{Da}$, and the presence of the complete series of $b$-type fragment ions (from $b_{2}$ to $b_{15}$ ), can be used to assign the sequence of this peptide as AEIDFSGIPEDIIKQI (Fig. 3B). Considering this sequence and the value of the molecular mass mentioned above, it may be suggested that the $\mathrm{C}$-terminal residue of this peptide is in the acidic form; therefore, the complete sequence of the peptide eluted at $34.2 \mathrm{~min}$ is AEIDFSGIPEDIIKQI-OH. This component was designated Pep 1.

The complete amino acid sequences of twenty-seven peptides were assigned using ESI-IT-TOF-MS and MS ${ }^{\mathrm{n}}$ analysis and are shown in a summarized form in Table 1 considering their presentation in decreasing order of molecular mass. A careful observation of Table 1 reveals that Pep-4 (NIALGQDQSGR-NH2), Pep-17 (VTLTLPPAES-NH2), Pep-21 (TVPDLEM-NH2), and Pep-22 (HGCIGCGR-NH2) present their $\mathrm{C}$-terminal residues in the amidated form. This is a characteristic feature of many peptide toxins from animal venoms; it is generally essential for their activities and important for their biostabilities $[42,51]$. It requires a Gly residue neighbor to the residue that will be the C-terminus; the Gly is used as a substrate for the amidation of the Cterminus, catalyzed by the enzyme alpha-peptidyl glycine amidating monooxidase (PAM). The terminal amidation of the $\mathrm{C}$-terminal residue of some scorpion venom peptides has been reported as part of the process of toxin maturation [42,54] C-terminal amidation in scorpion venom peptides have been reported by many authors [55-59].

Venom was extracted in the presence of a cocktail of proteinase inhibitors, indicating that the peptides sequenced did not result from artifacts of sample manipulation, such as uncontrolled proteolysis of high weight molecular proteins during venom extraction. Thus, the twenty-seven peptides sequenced were apparently physiologically produced, representing natural compounds present in the venom of $T$. obscurus. Once the peptide sequences were assigned, it was necessary to verify whether each peptide could be functionally identified by individual sequences; this was achieved using the sequence alignment tool BLASTp (http://blast.ncbi.nlm.nih.gov/Blast.cgi?PROGRAM = blastp\&PAGE_TYPE $=$ BlastSearch\&LINK_LOC $=$ blasthome $)$. The searches were performed using the non-redundant protein sequences DB, considering the taxa Scorpiones (taxid: 6855), and using the algorithm blastp (protein-protein BLAST); searches with 100\% coverage, $100 \%$ identity, and E-values below 1e-04 were considered to correspond to the protein/peptide indicated in the hit, presenting the parameters mentioned above. The searches identified Pep 1 (AEIDFSGIPEDIIKQI$\mathrm{OH}$ ) and Pep 7 (KETNAKPPA-OH) as corresponding to fragments 1-16 of hypotensin-1 (100\% coverage, $100 \%$ identity, and an E-value of 1e$13)$, and $17-25$ of the hypotensin- 2 (100\% coverage, $100 \%$ identity, and an E-value of 8e-05), respectively, that were isolated from T. serrulatus venom. The peptide AEIDFSGIPEDIIKQIKETNAKPPA-OH was initially identified as fragment 1-25 of hypotensin-1 (100\% coverage, $100 \%$ identity, and an E-value of 8e-24), previously identified as TsHpt$\mathrm{Ib}$ in the venom of Tityus serrulatus [21]; this peptide was characterized as a bradykinin-potentiating peptide (BPP), i.e., an agonist of the B2 receptor of kinin, which does not inhibit the angiotensin-converting- 


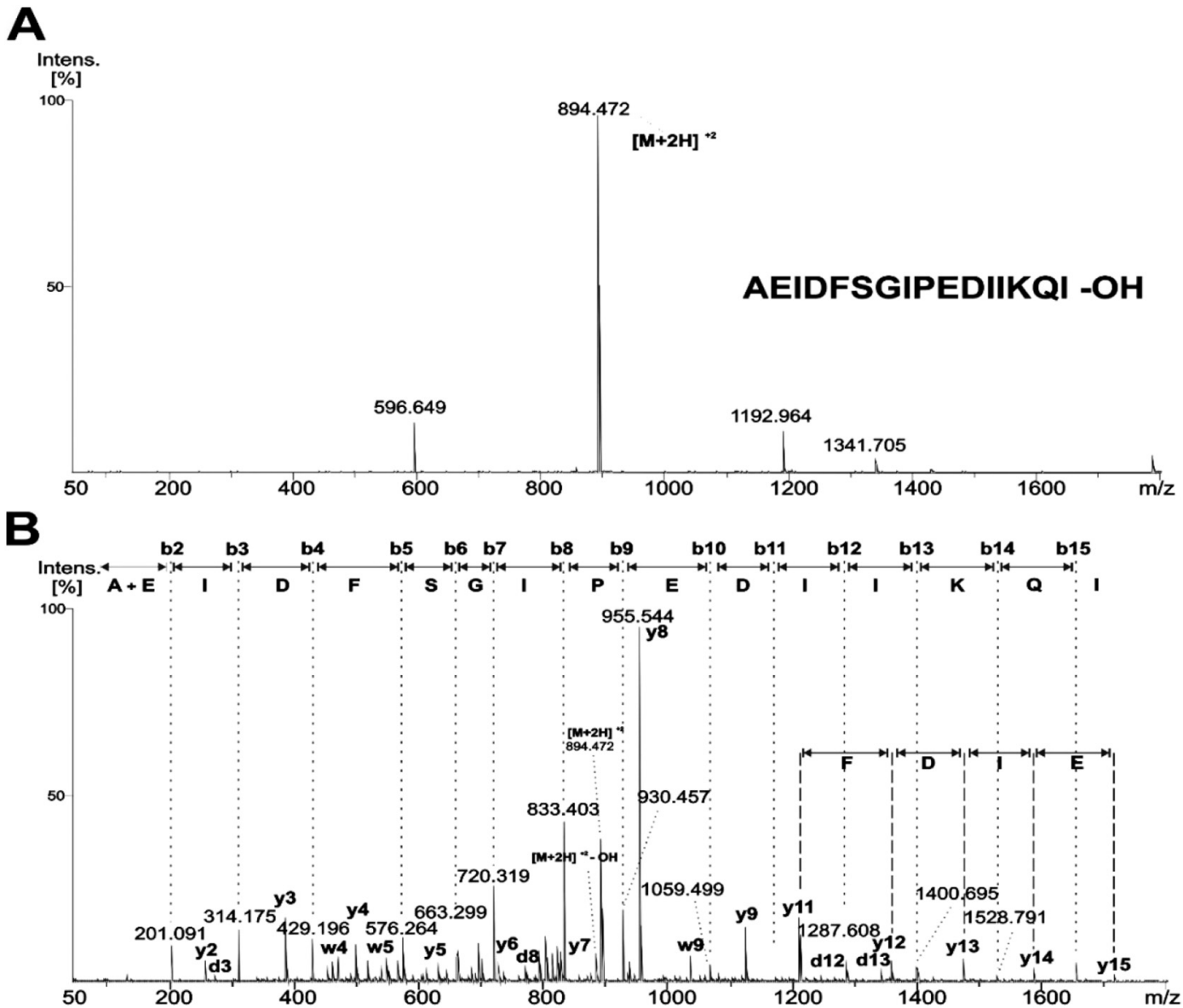

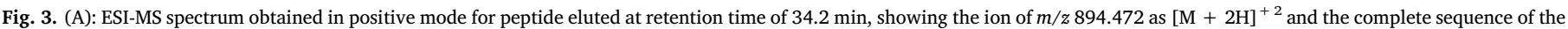

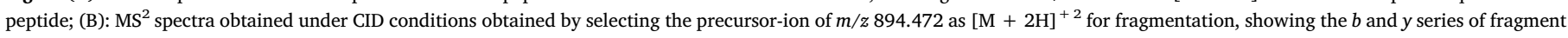

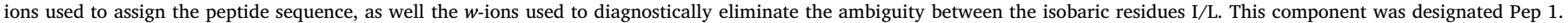

enzyme (ACE). Later, Verano-Braga et al. [60] described the analogs of TsHpt-Ib presenting the motif Lys-Pro-Pro in their sequences, which still maintained partial native biological activity of TsHpt-Ib, even in the short sequences. Therefore, Pep 1 (AEIDFSGIPEDIIKQI-OH), Pep 7 (KETNAKPPA-OH), Pep 11 (NAKPPA-OH), Pep 18 (KETNAKPP-OH), Pep 24 (NAKPP-OH) and Pep 27 (KPPA-OH) are partially conserved in the relation to TsHpt-Ib. Despite the use a cocktail of protease inhibitors during the extraction of these peptides from the crude venom, they can be considered fragments of TsHpt-Ib that already existed before peptide extraction from crude venom. Pep 1, Pep 7, Pep 11, Pep 18, Pep 24, and Pep 27 may have actions related to the induction of hypotension in victims of Tityus scorpion envenoming.

Pep 4 (NIALGQDQSGR-NH2) corresponds to the fragment 48-58 of the antigen 5 -like protein, a cysteine-rich allergen reported in the venom of T. serrulatus venom (100\% coverage, 100\% identity, and Evalue 1e-06); thus, Pep 4 may have action related to the antigen 5 function, i.e., a component with a potent effect on the activation of the immunological system of the victims, as also previously observed in patients allergic to the venom of social wasps [61]. Pep 3 (LIPNDQLRSI$\mathrm{OH}$ ) corresponds to the fragment 32-41 of tityustoxin Ka (TsTX-Ka) (100\% coverage, $100 \%$ identity, and E-value 1e-06; accession code Q0GY46). TsTX-Ka selectively blocks voltage-gated non inactivating $\mathrm{K}^{+}$channels in synaptosomes ( $\mathrm{IC}_{50}$ values of $8 \mathrm{nM}$ and $30 \mathrm{nM}$, respectively) [46,61-64]. Pep 5 (KIKEQLIEA-OH) corresponds to the fragment 36-42 of the potassium channel toxin TtrKIK (100\% coverage, $100 \%$ identity, and an E-value of 1e-06; accession code Q0GY45); this toxin also blocks voltage-gated potassium channels. These peptides may have action related to potassium channel impairment. TsTX-K $\alpha$ and TtrKIK appear to be involved in processes of regulation of cell excitability and physiology, such as heart-beating regulation, neurotransmitter release, signal transduction and cell proliferation [65].

Rates et al. [42] reported a series of linear peptides in T. serrulatus venom, from which twenty-eight components corresponded to fragments of Pape proteins; ten corresponded to fragments of the N-terminal region of the TsKb toxin (scorpine-like), potassium channel toxins (other than the k-beta type) and hypotensins-1 and -2. In the present investigation, component Pep 5 (KIKEKLIEA-OH) is likely a fragment from the pro-peptide region of the $\beta$-KTx neurotoxin, while Pep 26 (SILK-OH) seems to be a fragment of the C-terminal region of the peptide KLVALIPNDQLRSILKAVVH, which was previously reported in T. serrulatus venom [42] without any known functional role.

Recently, Pucca et al. [46] reported three novel NDBPs from Tityus serrulatus venom: RIRSKGKK, RIRSKG, and KIWRS. None of these peptides presented analogous components in T. obscurus venom. These peptides were able to modulate macrophage responses, increasing the production of IL-6, and inhibiting the activity of the angiotensin-converting enzyme. The short, linear peptides (generally shorter than eight amino acid residues) are too reduced to generate reliable identification as natural peptides, and their searches usually result in very redundant protein identification. Only eight of twenty-seven peptides were identified by their sequences; nineteen were not functionally identified based on their amino acid sequences. Thus, we selected Pep 1 to Pep 13 to be synthesized and functionally assayed.

\subsection{Bioassays}

As most NDBPs assigned in the present study could not be identified by their sequences, we decided to synthesize Pep 1 to Pep 13 in the 
Table 2

Profile of biological activities of short and linear peptides from venom of the scorpion T. obscurus.*

\begin{tabular}{|c|c|c|c|c|c|}
\hline Peptides & Sequences & Hemolysis & Mast cell degranulation & LDH release & $\mathrm{MIC}^{* *}(\mu \mathrm{g} / \mu \mathrm{L})$ \\
\hline Pep-1 & AEIDFSGIPEDIIKQI-OH & ++ & - & - & $>500$ \\
\hline Pep-2 & GCDALLSGDHGGLLSANGC-OH & + & - & + & $>500$ \\
\hline Pep-3 & LIPNDQLRSI-OH & - & - & - & $>500$ \\
\hline Pep-4 & NIALGQDQSGR-NH2 & - & - & + & $>500$ \\
\hline Pep-5 & KIKEKLIEA-OH & ++ & - & + & $>500$ \\
\hline Pep-6 & WPNKIEPGK-OH & + & - & - & $>500$ \\
\hline Pep-7 & KETNAKPPA-OH & + & - & + & $>500$ \\
\hline Pep-8 & KIITPPIR-OH & - & - & - & $>500$ \\
\hline Pep-9 & KPVEPVG-OH & ++ & - & + & $>500$ \\
\hline Pep-10 & SESNTCG-OH & ++ & - & - & $>500$ \\
\hline Pep-11 & NAKPPA-OH & ++ & - & + & $>500$ \\
\hline Pep-12 & ILTGKLKCK-OH & - & - & - & $>500$ \\
\hline Pep-13 & ILPNDK-OH & - & - & - & $>500$ \\
\hline
\end{tabular}

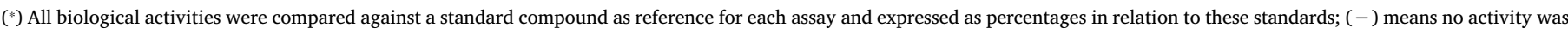

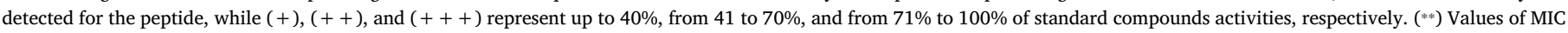
were observed for both Gram-positive and Gram-negative bacteria.

solid phase, purify them, and submit them to a series of functional bioassays such as hemolysis, delivery of LDH from mast cells, mast cell degranulation, antibiosis, nociception, edema formation, and evaluation of locomotion/rearing.

The results for the tests of biological activities were expressed compared to the standard compounds used in the assay of hemolysis, release of LDH from mast cells, mast cell degranulation, (Figs. S27 to S29), and antibiosis (Table 2). To summarize these results, it was established that an activity was considered weak $(+)$, moderate $(++)$, or strong $(+++)$ when it represented $20 \%$ to $40 \%, 41 \%$ to $70 \%$, or $\geq 71 \%$, respectively, of the activity of the standard compound of each assay (Table 2).

In general, no peptide presented mast cell degranulation (Fig. S29) and antimicrobial effects (Table 2). The peptides Pep 1, Pep 5, Pep 9, Pep 10 and Pep 11 presented moderate hemolytic activity at physiological concentrations (micromolar range) (Fig. S27), suggesting that these peptides interact with the plasma membrane of erythrocytes, disturbing their structure and causing hemoglobin delivery. The same peptides presented no antibiosis, indicating that they have no affinity for the anionic membrane of bacteria. Meanwhile, the peptides Pep 2, Pep 4, Pep 5, Pep 7, Pep 9 and Pep 11 presented a weak releasing effect of LDH from mast cells at physiological concentrations (Fig. S28). If it is considered that these peptides have very reduced or no activity of LDH delivered from mast cells, these results together suggest that the interaction of Pep 1, Pep 5, Pep 9, Pep 10, and Pep 11 with the zwitterionic lipids of the plasma membrane from the erythrocyte membrane are highly selective (or at least have high affinity). The inactivity of these peptides in relation to mast cell degranulation indicates that none presented any affinity for G-protein coupled receptors responsible for mast cell exocytosis.

The synthesized peptides were evaluated for mechanical algesia (Fig. S30) and edema formation at three different times (60, 180, and $300 \mathrm{~min}$ ) after peptide administration (Fig. S31). Table 3 summarizes the results. The signal $(*)$ indicates the statistical significance: ${ }^{*} \mathrm{p}<0.5,{ }^{* *} \mathrm{p}<0.01$, and ${ }^{* * *} \mathrm{p}<0.001 ;(-)$ indicates no significance, as determined by two-way ANOVA. The detailed graphic data for these assays is shown in the supplementary data (Figs. S30 to S31). The peptides Pep 1, Pep 7, Pep 9, Pep 10 and Pep 11 caused a significant increase in nociceptive sensibility during all test times; peptides Pep 4, Pep 5, Pep 6, and Pep 8 showed a moderate increase in nociceptive sensibility over a short time, and this activity appears to disappear for up to $300 \mathrm{~min}$; the other peptides presented no significant response in this test (Fig. S30). Fig. S31 shows that most peptides produced weak edema; Pep 5 and Pep 11 caused moderated edema between 60 and $300 \mathrm{~min}$.

Table 3 summarizes edema formation; it was observed in the presence of Pep 1, Pep 3, Pep 4, Pep 5, Pep 11 and Pep 13 (Fig. S31). Pep 11 shows more intense activity $(\mathrm{p}<0.01)$ during the $300 \mathrm{~min}$ of the assay. The other peptides caused very reduced or no edema formation. Meanwhile, Pep 6, Pep 7, Pep 9, Pep 10, Pep 11, Pep 12, and Pep 13 caused hypernociception in the animals.

Comparing the activities of peptides with some conservation of their sequences, such as Pep 7 (KETNAKPPA-OH) and Pep 11 (NAKPPA-OH), the presence of some extra amino acids in the sequence of Pep 7 makes it less hemolytic and causes no edema but has a greater effect on nociception than Pep 11 (Tables 2 and 3). Both peptides must present a net charge of +1 at $\mathrm{pH}$ 7.0. The effects on nociception may be related to a better fit of the longer chain of Pep 7 to the pain receptors than Pep 11.

The open field test is used to evaluate the effects of the compounds in the pattern of the movements of the model animals. The open field tests access the exploratory activity of mice, trying to correlate the sequences of some repeated motions with inputs acquired during the exploration of new environments [66]. In this test, the locomotion of an anxious animal is strikingly diminished; in contrast, animals that are comfortable generally spend more time in the peripheral areas, and some alterations can occur, such as a reduction in rearing and grooming $[67,68]$. In this test, an increase in the number of squares (central and peripheral) of the observation arena represents an anxiolytic activity. The general activity shows that peptides Pep 4, Pep 5 and Pep 9 cause a significant alteration in rearing, while Pep 1, Pep 2, Pep 3, Pep 7, Pep 8 and Pep 11 reduce locomotion (Figs. S32 to S33). Table 3 summarizes the results of mechanical hyperalgesia, edema formation and the effects observed in open field tests (rearing and locomotion).

\section{Conclusions}

T. obscurus is an endemic species from North Brazil, where it is responsible for many scorpion incidents every year that result in severe envenoming. The major portion of this venom (approximately 70\%) is composed of peptides, but NDBPs correspond to $5 \%$ of the crude venom. Despite the high number of NDBPs detected, only a few peptides have been structurally and functionally characterized. In the present study, T. obscurus venom was submitted to mass spectrometric analysis to profile its peptidome. Twenty-seven major peptides among the NDBPs were sequenced, and thirteen were synthetized and functionally characterized. Some of the novel peptides showed similarity to hypotensins, potassium channel toxins and the allergen 5 protein, but most do not match any known toxin.

Despite the prey-killing function, scorpion venom is generally not lethal to predators (humans, monkeys, birds, bears, and other animals). The venom is principally used to promote actions in victims due to 
Table 3

Profile of oedematogenic, nociceptive, rearing and locomotion activities of short and linear peptides from venom of scorpion T. obscurus.

\begin{tabular}{|c|c|c|c|c|c|c|c|c|c|}
\hline \multirow[t]{2}{*}{ Peptides } & \multirow[t]{2}{*}{ Sequences } & \multicolumn{3}{|c|}{ Oedema formation } & \multicolumn{3}{|c|}{ Nociception } & \multirow{2}{*}{$\begin{array}{l}\text { Rearing } \\
-\end{array}$} & \multirow{2}{*}{$\begin{array}{l}\text { Locomotion } \\
-\end{array}$} \\
\hline & & $60 \mathrm{~min}$ & $180 \mathrm{~min}$ & $300 \mathrm{~min}$ & $60 \mathrm{~min}$ & $180 \mathrm{~min}$ & $300 \mathrm{~min}$ & & \\
\hline Pep-1 & AEIDFSGIPEDIIKQI-OH & * & - & *** & $* * *$ & $* * *$ & $* * *$ & - & $* * *$ \\
\hline Pep-2 & GCDALLSGDHGGLLSANGC-OH & - & - & - & - & - & - & - & * \\
\hline Pep-3 & LIPNDQLRSI-OH & $*$ & $* * * *$ & $* *$ & - & - & - & - & $* * *$ \\
\hline Pep-4 & NIALGQDQSGR-NH2 & $* * *$ & $* *$ & - & $*$ & - & - & $* * *$ & - \\
\hline Pep-5 & KIKEKLIEA-OH & $* * *$ & $*$ & $* *$ & $*$ & - & - & $* * *$ & - \\
\hline Pep-6 & WPNKIEPGK-OH & - & - & - & $* * *$ & ** & - & - & - \\
\hline Pep-7 & KETNAKPPA-OH & - & - & - & $* * *$ & $* * *$ & $* * *$ & - & $* * *$ \\
\hline Pep-8 & KIITPPIR-OH & $*$ & - & - & $*$ & - & - & - & $* * * *$ \\
\hline Pep-9 & KPVEPVG-OH & - & - & - & $* *$ & $* * *$ & $*$ & $* * *$ & - \\
\hline Pep-10 & SESNTCG-OH & - & - & - & $* * *$ & $* * *$ & $* * *$ & - & - \\
\hline Pep-11 & NAKPPA-OH & $* * *$ & $* * *$ & **** & $*$ & $* *$ & $* * *$ & - & $* * * *$ \\
\hline Pep-12 & ILTGKLKCK-OH & $* *$ & - & - & $* * *$ & $* * *$ & $* * *$ & - & $* * *$ \\
\hline Pep-13 & ILPNDK-OH & $* *$ & - & $* * * *$ & $*$ & $* *$ & $* * *$ & - & $* * *$ \\
\hline
\end{tabular}

(-) no significance.

${ }^{*} \mathrm{p}<0.5$.

${ }^{* * *} \mathrm{p}<0.01$.

***** $\mathrm{p}<0.001$

uncomfortable pain and inflammatory actions caused by venom toxins, which are mainly peptides.

According to the results above, the NDBPs of this venom act synergistically and are multifunctional toxins, causing a series of actions in the victims/prey of $T$. obscurus stings. This potentiates inflammatory processes; some peptides may also alter rearing or locomotion of victims/prey. Undoubtedly, information about the complexity of the peptides that constitute the venom of $T$. obscurus will contribute to a better understanding of the complex mechanism of envenoming pathogenesis caused by this venom.

\section{Transparency document}

The http://dx.doi.org/10.1016/j.jprot.2017.09.006 associated with this article can be found, in online version.

\section{Acknowledgements}

This work was supported by a grant from the São Paulo State Research Foundation (FAPESP, BIOprospecTA program 2011/51684-1 and INCT Program/iii-CNPq/MCT). N.B.D. is a postdoctoral fellow from the CAPES/Toxinology Program (AUX-PE-TOXINOLOGIA-1207/2011, $1208 / 2011$ and 1230/2011), and M.S.P. is researching for CNPq.

\section{Conflict of interest}

The authors declare that they have no conflict of interest.

\section{Appendix A. Supplementary data}

Supplementary data to this article can be found online at http://dx. doi.org/10.1016/j.jprot.2017.09.006.

\section{References}

[1] W.R. Lourenço, E.A. Leguin, The true identity of scorpion (Atreus) obscurus Gervais, 1843 (Scorpiones, Buthidae), Euscorpius 75 (2008) 1-9.

[2] P.P.O. Pardal, L.C. Castro, E. Jennings, J.S.O. Pardal, M.R. Monteiro, Epidemiological and clinical aspects of scorpion envenomation in the region of Santarém, Pará, Brazil, Rev. Soc. Bras. Med. Trop. 36 (2003) 349-353.

[3] J.P. Chippaux, M. Goyffon, Envenimations et intoxications par les animaux venimeux ou vénéneux: I. Généralités, Med. Trop. 66 (2006) 215-220.

[4] P.P.Q. Torrez, M.M.M. Quiroga, P.A. Abati, M. Mascheretti, W.S. Costa, L.P. Campos, F.O.S. França, Acute cerebellar dysfunction with neuromuscular manifestations after scorpionism presumably caused by Tityus obscurus in Santarém, Pará/Brazil, Toxicon 96 (2015) 68-73.
[5] P.P. Pardal, E.A. Ishikawa, J.L. Vieira, J.S. Coelho, R.C. Dórea, P.A. Abati, M.M. Quiroga, H.M. Chalkidis, Clinical aspects of envenomation caused by Tityus obscurus (Gervais, 1843) in two distinct regions of Pará state, Brazilian Amazon basin: a prospective case series, J. Venomous Anim. Toxins Incl. Trop. Dis. 20 (2014) 3.

[6] P. Cupo, Clinical update on scorpion envenoming, Rev. Soc. Bras. Med. Trop. 48 (2015) 642-649.

[7] A.P. Santos-da-Silva, D.M. Candido, A.L.A. Nencioni, L.F. Kimura, J.P. PrezottoNeto, K.C. Barbaro, H.M. Chalkidis, V.A.C. Dorce, Some pharmacological effects of Tityus obscurus venom in rats and mice, Toxicon 126 (2017) 51-58.

[8] C.V.F. Batista, F. Gomez-Lagunas, S. Lucas, L.D. Possani, Tc1, from Tityus cambridgei, is the first member of a new subfamily of scorpion toxin that blocks $\mathrm{K} \beta$ channels, FEBS Lett. 486 (2000) 117-120.

[9] C.V.F. Batista, F.Z. Zamudio, S. Lucas, J.W. Fox, A. Fra, G. Prestipino, L.D. Possani, Scorpion toxins from Tityus cambridgei that affect $\mathrm{Na}(\alpha)$ e channels, Toxicon 40 (2002) 557-562.

[10] C.V. Batista, F. Gomez-Lagunas, R.C. Rodriguez de la Vega, P. Hajdu, G. Panyi, R. Gaspar, L.D. Possani, Two novel toxins from the Amazonian scorpion Tityus cambridgei that block Kv1.3 and Shaker B K( $\beta$ )-channels with distinctly different affinities, Biochim. Biophys. Acta 1601 (2002) 123-131.

[11] C.V.F. Batista, L.D. Pozo, F.Z. Zamudio, S. Contreras, B. Becerril, E. Wanke, L.D. Possani, Proteomics of the venom from the Amazonian scorpion Tityus cambridgei and the role of prolines on mass spectrometry analysis of toxins, J. Chromatogr. B Anal. Technol. Biomed. Life Sci. 803 (2004) 55-66.

[12] A.R. Murgia, C.V.F. Batista, P. Gianfranco, L.D. Possani, Amino acid sequence and function of a new a-toxin from the Amazonian scorpion Tityus cambridgei, Toxicon 43 (2004) 737-740.

[13] J.A. Guerrero-Vargas, C.B.F. Mourão, V. Quintero-Hernandez, L.D. Possani, E.F. Schwartz, Identification and phylogenetic analysis of Tityus pachyurus and Tityus obscurus novel putative Nab-channel scorpion toxins, PLoS One 7 (2012) e30478, , http://dx.doi.org/10.1371/journal.pone.0030478.

[14] F. Luo, X.C. Zeng, R. Hahin, Z.J. Cao, H. Liu, W.X. Li, Genomic organization of four novel nondisulfide-bridged peptides from scorpion Mesobuthus martensii Karsch: gaining insight into evolutionary mechanism, Peptides 26 (2005) 2427-2433.

[15] X.C. Zeng, G. Corzo, R. Hahin, Scorpion venom peptides without disulfide bridges, IUBMB Life 57 (2005) 13-21.

[16] E. Zlotkin, E. Miranda, H.H. Rochat, Chemistry and pharmacology of scorpion venoms, in: S. Bettini (Ed.), Arthropod Venoms, Springer-Verlag, Berlin, 1978, pp. 317-370 (940 pp.).

[17] A.M. Pimenta, M.F. Martin-Eauclaire, H. Rochat, S.G. Figueiredo, E. Kalapothakis, L.C.C. Afonso, M.E. De Lima, Purification, amino-acid sequence and partial characterization of two toxins with anti-insect activity from the venom of the South American scorpion Tityus bahiensis (Buthidae), Toxicon 39 (2001) 100-1019.

[18] A.H. Rowe, Y. Xiao, J. Scales, K.D. Linse, M.P. Rowe, T.R. Cummins, H.H. Zakon, Isolation and characterization of CvIV4: a pain inducing $\alpha$-scorpion toxin, PLoS One 6 (2011) e23520.

[19] R.C.R. De la Vega, N. Vidal, L.D. Possani, Scorpion peptides, in: A. Kastin (Ed.), Handbook of Biologically Active Peptides, 1942 Elsevier, USA, 2013, pp. 423-429.

[20] L. Dai, G. Corzo, H. Naoki, M. Adriatsferana, T. Nakajima, Purification, structure-function analysis, and molecular characterization of novel linear peptides from scorpion Opisthacanthus madagascariensis, Biochem. Biophys. Res. Commun. 293 (2002) 1514-1522.

[21] T. Verano-Braga, C. Rocha-Resende, D.M. Silva, D. Ianzer, M.F. Martin-Eauclaire, P.E. Bougis, M.E. De Lima, R.A.S. Santos, A.M.C. Pimenta, Tityus serrulatus hypotensins: a new family of peptides from scorpion venom, Biochem. Biophys. Res. Commun. 371 (2008) 515-520.

[22] B. Gao, J. Xu, M.C. Rodrigues, H. Lanz-Mendza, R. Hernandez-Rivas, W. Du, S. Zhu, Characterization of two linear cationic antimalarial peptides in the scorpion 
Mesobuthus eupeus, Biochimie 92 (2010) 350-359.

[23] Z. Li, X. Xu, L. Meng, Q. Zhang, L. Cao, W. Li, Y. Wu, Z. Cao, Hp1404, a new antimicrobial peptide from the Scorpion Heterometrus petersii, PLoS One 9 (2014) e97539.

[24] C.A. Hernandez-Aponte, J. Silva-Sanchez, V. Quintero-Hernandez, A. RodriguezRomero, C. Balderas, L.D. Possani, G.B. Gurrola, Vejovine, a new antibiotic from the scorpion venom of Vaejovis mexicanus, Toxicon 57 (2011) 84-92.

[25] P.L. Harrison, M.A. Abdel-Rahman, K. Miller, P.N. Strong, Antimicrobial peptides from scorpion venoms, Toxicon 88 (2014) 115-137.

[26] N.B. Dias, B.M. de Souza, P.C. Gomes, M.S. Palma, Peptide diversity in the venom of the social wasp Polybia paulista (Hymenoptera): a comparison of the intra- and inter-colony compositions, Peptides 51 (2014) 122-130.

[27] N.B. Baptista-Saidemberg, D.M. Saidemberg, M.S. Palma, Profiling the peptidome of the venom from the social wasp Agelaia pallipes pallipes, J. Proteome 74 (2011) 2123-2137.

[28] L.D. Santos, A.R.S. Menegasso, J.R.A. Dos Santos-Pinto, K.S. Santos, F.M. Castro, J.E. Kalil, M.S. Palma, Proteomic characterization of the multiple forms of the PLAs from the venom of the social wasp Polybia paulista, Proteomics 11 (2011) $1403-1412$.

[29] N.B. Dias, B.M. De Souza, P.C. Gomes, P. Brigatte, M.S. Palma, Peptidome profiling of venom from the social wasp Polybia paulista, Toxicon 107B (2015) 290-303.

[30] J.R.A. Dos Santos-Pinto, E.G.P. Fox, D.M. Saidemberg, L.D. Santos, A.R.S. Menegasso, E. Costa-Manso, E.A. Machado, O.C. Bueno, M.S. Palma, A proteomic view of the venom from the fire ant Solenopsis invicta Buren, J. Proteome Res. 11 (2012) 4643-4653.

[31] V.M.F. Resende, A. Vasilj, K.S. Santos, M.S. Palma, A. Shevchenko, Proteome and phosphoproteome of Africanized and European honeybee venoms, Proteomics 13 (2013) 2638-2648.

[32] L.D. Santos, N.B. Dias, J.R.A. Dos Santos-Pinto, M.S. Palma, Brown recluse spider venom: proteomic analysis and proposal of a putative mechanism of action, Protein Pept. Lett. 16 (2009) 933-944.

[33] J.R.A. Dos Santos-Pinto, A.M.C. Garcia, H.A. Arcuri, F.G. Esteves, H.C. Salles, G. Lubec, M.S. Palma, Silkomics: insight into the silk spinning process of spiders, J. Proteome Res. 15 (2016) 1179-1193.

[34] C.V.F. Batista, G. D'Suze, F. Gómez-Lagunas, F.Z. Zamudio, S. Encarnación, L. Possani, Proteomic analysis of Tityus discrepans scorpion venom and amino acid sequence of novel toxins, Proteomics 6 (2006) 3718-3727.

[35] C.V.F. Batista, S.A. Roman-Gonzalez, S.P. Salas-Castillo, F.Z. Zamudio, F. GomezLagunas, L.D. Possani, Proteomic analysis of the venom from the scorpion Tityus stigmurus: biochemical and physiological comparison with other Tityus species, Comp. Biochem. Physiol. C: Toxicol. Pharmacol. 146 (2007) 147-157.

[36] X. Xu, Z. Duan, Z. Di, Y. He, Z. Li, J. Li, C. Xie, X. Zenh, Z. Cao, Y. Wu, S. Liang, W. Li, Proteomic analysis of the venom from the scorpion Mesobuthus martensii, J. Proteome 106 (2014) 162-180.

[37] A.M. Pimenta, R. Stöcklin, P. Favreau, P.E. Bougis, M.F. Martin-Eauclaire, Moving pieces in a proteomic puzzle: mass fingerprinting of toxic fractions from the venom of Tityus serrulatus (Scorpiones, Buthidae), Rapid Commun. Mass Spectrom. 15 (2001) 1562-1572.

[38] F.M. Almeida, A.M.C. Pimenta, S.G. De Figueiredo, M.M. Santoro, M.F. MartinEauclaire, C.R. Diniz, M.E. De Lima, Enzymes with gelatinolytic activity can be found in Tityus bahiensis and Tityus serrulatus venoms, Toxicon 40 (2002) 1041-1045.

[39] U.C. Oliveira, D.M. Candido, V.A.C. Valquíria Abrão Coronado Dorce, I.L.M. Junqueira-de-Azevedo, The transcriptome recipe for the venom cocktail of Tityus bahiensis scorpion, Toxicon 95 (2015) 52-61.

[40] T. Verano-Braga, A.A.A. Dutra, I. Léon, M.N. Melo-Braga, P. Roepstorff, A.M.C. Pimenta, F. Kjeldsen, Moving pieces in a venomic puzzle: unrevealing posttranslationally modified toxins from Tityus serrulatus, J. Proteome Res. 12 (2013) 3460-3470.

[41] P. Favreau, L. Menin, S. Michalet, F. Perret, O. Cheneval, M. Stocklin, P. Bulet, R. Stocklin, Mass spectrometry strategies for venom mapping and peptide sequencing from crude venoms: case applications with single arthropod specimen, Toxicon 47 (2006) 676-687.

[42] B. Rates, K.F. Ferraz, M.H. Borges, M. Richardson, M.E. De Lima, A.M.C. Pimenta, Tityus serrulatus venom peptidomics: assessing venom peptide diversity, Toxicon 52 (2008) 611-618.

[43] D.G. Nascimento, B. Rates, D.M. Santos, T. Verano-Braga, A. Barbosa-Silva, A.A.A. Dutra, I. Biondi, M.F. Martin-Euclaire, M.E. De Lima, A.M.C. Pimenta, Moving pieces in a taxonomic puzzle: venom 2D-LC/MS and data clustering analyses to infer phylogenetic relationships in some scorpions from the Buthidae family (Scorpiones), Toxicon 46 (2006) 628-639.

[44] S.V. Sampaio, C.J. Laure, J.R. Giglio, Isolation and characterization of toxic proteins from the venom of the Brazilian scorpion Tityus serrulatus, Toxicon 21 (1983) 265-277.
[45] M.B. Pucca, F.A. Cerni, E.L. Pinheiro-Junior, K.F. Zoccal, K.C.F. Bordon, G. Fernanda Amorimn, S. Peigneur, K. Vriensd, K. Thevissend, B.P.A. Cammued, R.B. Martins Júnior, E. Arruda, L.H. Faccioli, J. Tytgat, E.C. Arantes, Non-disulfidebridged peptides from Tityus serrulatus venom: evidence for proline-free ACE-inhibitors, Peptides 82 (2016) 44-51.

[46] V. Quintero-Hernández, J.M. Jiménez-Vargas, G.B. Gurrola, H.H.F. Valdivia, L.D. Possani, Scorpion venom components that affect ion-channels function, Toxicon 76 (2013) 328-342.

[47] J. Meletiadis, J.G.M. Meis, J.W. Mouton, J.P. Donnelly, P.E. Verweij, Comparison of NCCLS and 3-(4,5-dimethyl-2-thiazyl)-2,5-diphenyl-2H-tetrazolium bromide (MTT) methods of in vitro susceptibility testing of filamentous fungi and development of a new simplified method, J. Clin. Microbiol. 38 (2000) 2949-2954.

[48] M. Zimmermann, Ethical guidelines for investigations of experimental pain in conscious animals, Pain 16 (1983) 109-110.

[49] R.A. Bailey, Design of Comparative Experiments, Cambridge University Press, Cambridge, 2008.

[50] J. Kyte, R.F. Doolittle, A simple method for displaying the hydropath Gesquiere ic character of protein, J. Mol. Biol. 157 (1982) 105-132.

[51] J.C. Gesquiere, E. Diesis, Slow isomerization of some proline-containing peptides inducing peak splitting during reversed-phase high-performance liquid chromatography, J. Chromatogr. A 478 (1989) (1989) 121-129.

[52] B. Tripet, D. Cepeniene, J.M. Kovacs, C.T. Mant, O.V. Krokhin, R.S. Hodges, Requirements for prediction of peptide retention time in reversed-phase high-performance liquid chromatography: hydrophilicity/hydrophobicity of side-chains at the $\mathrm{N}$ - and $\mathrm{C}$-termini of peptides are dramatically affected by the end-groups and location, 1141 (2009) 212-225.

[53] C.E. Eyers, C. Lawless, D.C. Wedge, K.W. Lau, J. Simon, S.J. Gaskell, S.J. Hubbard, CONSeQuence: prediction of reference peptides for absolute quantitative proteomics using consensus machine learning approaches, Mol. Cell. Proteomics (2011), http://dx.doi.org/10.11/10.1074/mcp.M110.003384-1.

[54] A.F. Bradbury, D.G. Smyth, Biosynthesis of the C-terminal amide in peptide hormones, Biosci. Rep. 7 (1987) 907-915.

[55] M.F. Martin-Eauclaire, B. Ceard, A.M. Ribeiro, C.R. Diniz, H. Rochat, P.E. Bougis, Molecular cloning and nucleotide sequence analysis of a cDNA encoding the main beta-neurotoxin from the venom of the South American scorpion Tityus serrulatus, FEBS Lett. 302 (1992) 220-222.

[56] C.V. Batista, G. D'Suze, F. Gomez-Lagunas, F.Z. Zamudio, S. Encarnacion, C. Sevcik, L.D. Possani, Proteomic analysis of Tityus discrepans scorpion venom and amino acid sequence of novel toxins, Proteomics 6 (2006) 3718-3727.

[57] E. Diego-Garcia, C.V.F. Batista, B.I. Garcia-Gomez, S. Lucas, D.M. Candido, F. Gomez-Lagunas, L.D. Possani, The Brazilian scorpion Tityus costatus Karsch: genes, peptides and function, Toxicon 45 (2005) 273-283.

[58] A. Almaaytah, Q. Albalas, Scorpion venom peptides with no disulfide bridges: A review, Peptides 51 (2014) 35-45.

[59] J. Barona, C.V. Batista, F.Z. Zamudio, F. Gomez-Lagunas, E. Wanke, R. Otero, L.D. Possani, Proteomic analysis of the venom and characterization of toxins specific for Nap- and Kp-channels from the Colombian scorpion Tityus pachyurus, Biochim. Biophys. Acta 1764 (2006) 76-84.

[60] T. Verano-Braga, F. Figueiredo-Rezende, M.N. Melo, R.Q. Lautner, E.R.M. Gomes, L.T. Mata-Machado, A.M. Murari, C. Rocha-Resende, M.E. de Lima, S. Guatimosim, R.S.A.S. Santos, A.M.C. Pimenta, Structure-function studies of Tityus serrulatus Hypotensin-I (TsHpt-I): a new agonist of B2 kinin receptor, Toxicon 56 (2010) 1162-1171.

[61] R.S. Rogowski, B.K. Krueger, J.H. Collins, M.P. Blaustein, Tityustoxin Ka blocks voltage-gated noninactivating $\mathrm{K}+$ channels and unblocks inactivating $\mathrm{K}+$ chan nels blocked by $\alpha$-dendrotoxin in synaptosomes, Proc. Natl. Acad. Sci. U. S. A. 91 (1994) 1475-1479.

[62] C. Legros, B. Ceard, P.E. Bougis, M.F. Martin-Eauclaire, Evidence for a new class of scorpion toxins active against K + channels, FEBS Lett. 431 (1998) 375-380.

[63] C.T. Cologna, S. Marcussi, J.R. Giglio, A.M. Soares, E.C. Arantes, Tityus serrulatus scorpion venom and toxins: an overview, Protein Pept. Lett. 16 (2009) 920-932.

[64] E. Diego-Garcia, E.F. Schwartz, G. D'Suze, S.A. Gonzalez, C.V. Batista, B.I. Garcia, R.C. de la Vega, L.D. Possani, Wide phylogenetic distribution of scorpine and longchain beta-KTx-like peptides in scorpion venoms: identification of 'orphan' components, Peptides 28 (2007) 31-37.

[65] O. Pongs, Regulation of Excitability by Potassium Channels, Results and Problems in Cell Differentiation, Springer Science, Business Media, 2007, pp. 145-161.

[66] R. Lalonde, C. Strazielle, Relations between open-field, elevated plus-maze, and emergence tests as displayed by C57/BL6J and BALB/c mice, J. Neurosci. Methods 171 (2008) 48-52.

[67] A. Sethi, B.P. Das, B.K. Bajaj, The anxiolytic activity of gabapentin in mice, J. App. Res. 5 (2005) 415-422.

[68] G.S. Sonovane, V.P. Sarveiya, V.S. Kasture, S.B. Kasture, Anxiogenic activity of Myristica fragrans seeds, Pharmacol. Biochem. Behav. 71 (2002) 239-244. 